The $6^{\text {th }}$ Conf. of SSFOP “Sustainable Development of Ornamental, Medicinal and Aromatic

Plants Scope”, Cairo, Egypt, 1/3/2020

Scientific J. Flowers \& Ornamental Plants

www.ssfop.com/journal

ISSN: 2356-7864

doi: 10.21608/sjfop.2020.91397

\title{
ASSESSMENT OF TOTAL PHENOLIC, FLAVONOID CONTENT, ANTIOXIDANT POTENTIAL AND HPLC PROFILE OF THREE MORINGA SPECIES LEAF EXTRACTS
}

\author{
Shams R. Abo El-Fadl*; A. Osman ${ }^{* *}$; A.M. Al-Zohairy ${ }^{* * *}$; Abeer A. Dahab* and Zakia A. \\ Abo El Kheir ${ }^{* * * *}$ \\ * Medicinal \& Aromatic Plants Res. Dept., Hort. Res. Inst., ARC, Giza, Egypt \\ ** Biochemistry Dept., Fac. Agric., Zagazig University, Egypt \\ *** Genetic Dept., Fac. Agric., Zagazig University, Egypt \\ **** Botany and Microbiology Dept., Fac. Sci. (Female), Al-Azhar University, Egypt
}

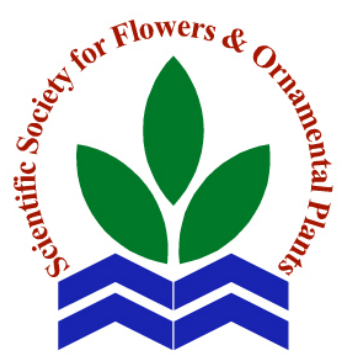

Scientific J. Flowers \& Ornamental Plants, 7(1):53-70 (2020).

Received: $16 / 1 / 2020$

Accepted: $10 / 2 / 2020$
ABSTRACT: In the current investigation, three selected Moringa species (M. stenopetala, $M$. peregrina and $M$. oleifera) grown at Orman Botanical Garden, Giza, Egypt were tested to quantify spectrometrically, the total phenolic compounds according to FolinCiocalteu's assay and flavonoids content to assess their corresponding effect on their antioxidative activity. Different leaf extracts (hexane, ethyl acetate and ethanol 70\%) of the three studied species were prepared. The obtained results revealed that $M$. peregrina gave the best extract yield for the leaves extracted by the different solvents. Regarding the total phenolic compounds, data exposed ethanol 70\% extract of $M$. peregrina leaves as the highest value among other species (11.66 $\mathrm{g}$ GAE/100 g extract), while it was for hexane extract that showed the highest value among other species in flavonoids content (7.21 g QE/100 g extract). Antioxidant activity of leaf extracts was evaluated by means of 2,2-dyphenyl-1-picrylhydrazyl (DPPH) and 2,2-azino-bis (3ethylbenzthiazoline-6-sulphonic acid (ABTS) scavenging assays. Data exhibited $M$. peregrina as the highest species to afford free radical scavenging activity with DPPH and ABTS assays in all concentrations of all extracts especially, $1000 \mu \mathrm{g} / \mathrm{ml}$ of ethanol (70\%) with 97.00 and 92.67\% inhibition, respectively. Moreover, HPLC with UV detection was employed for the identification and quantification of the phenolic compounds and flavonoid content, present in leaf methanolic extracts of the studied species. HPLC assay identified 25 phenolic compounds and 11 flavonoids in the leaves. It was noticed that $M$. stenopetala leaves emerged the highest values in most of the phenolic compounds and flavonoids. Eventually, it can be concluded that Moringa leaves showed their certain nutritional value and therefore had the potential as source of natural antioxidants. In addition, their regular consumption in diet could provide health benefits to humans by their protection role against oxidative stress.

Key words: Moringa species, antioxidant activity, total flavonoids, total phenols, HPLC. 


\section{Shams R. Abo El-Fadl et al.}

\section{INTRODUCTION}

Moringaceae is a fast-growing, droughtresistant flowering plant family which is treasured by ancient Egyptians, the Greeks and Romans for its nutritional and medicinal aspects. Moringa is the sole genus of the family with around 33 species of which 4 are accepted i.e. $M$. oleifera, $M$. ovalifolia, $M$. peregrina and $M$. stenopetala (Mabberley, 1987). It is found mostly, in semi-arid, tropical, and subtropical areas in the Horn of Africa, Madagascar, Southwestern Africa and tropical Asia to Westward in Egypt and grows in almost all phytogeographical regions as reported by NRC (2006) and Mridha (2015). Moringa species have a medico-socioeconomic role that can be considered as a bioreactor, producing large number of organic molecules through metabolic processes which are divided into primary metabolites as proteins, carbohydrates, lipids etc. and secondary metabolites as alkaloids, carotenoids, moringine, moringinine, phytoestrogens, caffeoylquinic acids, tannins, phytosterols, terpenoids, glycosides, flavonoids and phenolic compounds (Anwar et al., 2007). The bioactive secondary metabolites have been shown to reduce the risk and progression of diseases such as cancer, cardiovascular, neurodegenerative diseases etc., by scavenging free radicals through various biological mechanisms.

As mentioned in Harborne and Herbert (1993), there are about eight thousand naturally occurring plant phenolics and about half this number are flavonoids. Phenolics are the largest group of phytochemicals that account for most of the antioxidant activity in plants or plant products (Sulaiman et al., 2013) while flavonoids are the largest group of naturally occurring phenolic compounds, which occur in different plant parts both in free state or as glycosides. Flavonoids are particularly beneficial, acting as anti-oxidants and giving protection against cardiovascular disease, certain forms of cancer and age related degeneration of cell components. Their polyphenolic nature enables them to scavenge injurious free radicals such as super oxide and hydroxyl radicals (Dewick, 2001).

Numerous antioxidant methods and modifications have been proposed to evaluate the antioxidant activity of some plants and to explain how antioxidants function. For instance, total antioxidant activity, DPPH assay and ABTS assay commonly used for the evaluation of the antioxidant activities of plant extracts (Chang et al., 2002). According to Al-Kahtani (1995), Moringa species possess an antioxidant activity and as Dillard and German (2000) assessed, M. oleifera is able to extend the period of food containing fats due to the presence of several sorts of antioxidant compounds such as flavonoids, ascorbic acid, carotenoids and phenolics. In another study of Akbar and Al-Yahya (2011), it was found that extracts of the aerial parts of the Arabian $M$. peregrina contains flavonoids, tannins, sterols/ triterpenes and saponins which have a significant effect on stimulating central nervous system activities. In a similar research, Fakurazi et al. (2012) confirmed this study findings about the concentrations of total phenolic compounds and total flavonoids content in the leaves of M. oleifera ethanolic extract which exhibited high antioxidant capacity of DPPH in the leaves.

Due to the fact that plant extracts usually occur as a combination of various types of bioactive compounds with different polarities, their separation still remains as big challenge for the process of their identification and characterization. It is a common practice in isolation of these bioactive compounds that a number of different separation techniques such as ThinLayer Chromatography (TLC), Column Chromatography, Flash Chromatography, Sephardim Chromatography and High Performance Liquid Chromatography (HPLC), should be used to obtain pure compounds (Martin and Guiochon, 2005). HPLC as a tool to determine the quantitative analysis of phenols and flavonoids makes it easy to proceed the most effective and abundant bioactive compounds in the 
different plant parts' extracts which also helps to differentiate species in a distinctive way as mentioned by Nouman et al. (2016) and Maqsood et al. (2017).

In accordance with the strong evidence of biological efficacy of phenolic compounds and flavonoids, the study was focused on the evaluation of total phenolic compounds and flavonoids, to estimate their antioxidant potency and to determine their presence qualitatively and quantitatively using HPLC assay (High Performance Liquid Chromatography). In the present study, three Moringa species i.e. M. stenopetala, $M$. peregrina and $M$. oleifera grown at Orman Botanical Garden, Giza, Egypt were screened for their total phenolic compounds and flavonoid contents, their antioxidant potency and their presence with values as well in different leaf extracts.

\section{MATERIALS AND METHODS}

This study was carried out at the Biochemistry Department, Faculty of Agriculture, Zagazig University during 2017 to assess total phenolic compounds and flavonoids in three Moringa species ( $M$. stenopetala, $M$. peregrina and $M$. oleifera) leaves isolated by different extracts namely; hexane, ethyl acetate and ethanol $70 \%$. Likewise, the antioxidant activity of different leaf extracts were defined. HPLC mechanism has been utilized to quantify and identify the different phenolic compounds and flavonoids in the methanolic leaf extracts of each species.

\section{Chemicals:}

Quercetin, gallic acid, and DPPH were procured from Sigma Aldrich, India. FolinCiocalteu reagents were purchased from S. D. Fine Chem Limited, India. Aluminium chloride and potassium acetate were purchased from Ranchem, India. Ethanol $70 \%$, hexane, ethyl acetate, sodium carbonate, potassium persulphate and methanol were purchased from El-Nasr Company for Chemical Industries, Cairo, Egypt. All chemicals and solvents used were of analytical grade.

\section{Plant materials:}

Fresh leaves of three Moringa species ( $M$. stenopetala, $M$. peregrina and $M$. oleifera) were collected randomly from Orman Botanical Garden, Giza, Egypt during May 2017. The studied species have been identified and authenticated by Prof. Dr. Abo El-Fetoh Mohamed AbdAlla, the Chairman of the board for the Egyptian Scientific Society of Moringa, National Research Center, Dokki, Egypt. Samples were air-dried, then ground by an electric miller to a fine powder, kept in a dry place and stored in paper bags until use.

\section{Preparation of defatted Moringa leaves flour:}

In order to break down complexes between phenols and proteins/carbohydrates in Moringa leaves, they were manually cleaned and ground for 3 min using a Moulinex mixer (Type 716, France) at the maximum speed setting and the meals were ground to pass through a $1.0 \mathrm{~mm}^{2}$ sieve. The powder was then defatted using n-hexane and the fat content was determined by AOAC (2000). Solvent was evaporated by a rotaryevaporator under reduced pressure and the dried-defatted meal was stored at $4{ }^{\circ} \mathrm{C}$ until sample extraction.

\section{Preparation of Moringa extracts:}

Twenty grams of each leaf sample of the studied species were extracted individually with different solvents $(200 \mathrm{ml})$ of hexane, ethyl acetate and ethanol $70 \%$ using magnetic stirrer for $2 \mathrm{~h}$ at room temperature. The extracts were filtered using a Buckner funnel and Whatmann No. 1 filter paper. Each filtrate of hexane and ethyl acetate was concentrated to dryness in a rotary evaporator (Büchi-Water-Bath-B-480) under reduced pressure and controlled temperature below $40^{\circ} \mathrm{C}$ to give final extracts, which were stored at $4{ }^{\circ} \mathrm{C}$ in an airtight container until further use. Ethanol 70\% extracts were freeze- dried (Thermo- electron Corporation - Heto power dry LL 300 Freezedryer). 


\section{Yield extracts:}

The dried extracts after evaporation and lyophilization of solvents were weighed to determine the yield and stored at $-20{ }^{\circ} \mathrm{C}$ until analysis carrying out. The extracts, were then, subjected to a phytochemical screening for plant secondary metabolites as flavonoids and phenolic compounds. The yield of the lyophilized extracts based on dry weight basis was calculated as the following equation:

Yield $(\mathrm{g} / 100 \mathrm{~g}$ of dry plant material $)=(\mathrm{W} 1 \times$ 100)/ W2

where W1 is the weight of the extract after solvent evaporation and W2 is the weight of the dry plant material.

\section{Quantitative estimation of total phenolics content (TPC):}

The total phenolic compounds content in all extracts were determined according to Kähkönen et al. (1999) by introducing $200 \mu \mathrm{l}$ of samples with two replicates into test tubes; $1.0 \mathrm{ml}$ of Folin-Ciocalteu's reagent (diluted $1: 10$ with deionized water) and $0.8 \mathrm{ml}$ of sodium bicarbonate solution $(7.5 \% \mathrm{w} / \mathrm{v})$ were added. A reagent blank using distilled water was prepared. The tubes were allowed to stand for $30 \mathrm{~min}$ at room temperature. Absorbance against the reagent blank was determined at $765 \mathrm{~nm}$ with an UV spectrophotometer UK (Jenway-6405UV/VIS). The mean of three readings was used and the results were expressed as grams of gallic acid equivalent (GAE) in $100 \mathrm{~g}$ of the extract. Calculations based on the calibration curve using the following linear equation:

$\mathrm{Y}=0.001 \mathrm{X}+0.0563\left(\mathrm{R}^{2}=0.9792\right)$

\section{Quantitative estimation of total flavonoids content (TFC):}

Half milliliter of each extract, $1.5 \mathrm{ml}$ of $95 \%$ ethanol, $0.1 \mathrm{ml}$ of $10 \%$ aluminum chloride, $0.1 \mathrm{ml}$ of $1 \mathrm{M}$ potassium acetate and $2.8 \mathrm{ml}$ dist. $\mathrm{H}_{2} \mathrm{O}$ were mixed together and incubated for $30 \mathrm{~min}$ at room temperature. A reagent blank using distilled water was prepared. The absorbance was measured at $420 \mathrm{~nm}$ according to Ordonez et al. (2006) for all extracts and the blank using UV spectrophotometer UK (Jenway-6405UV/VIS). The mean of three readings was used and the results were expressed as grams of quercetin equivalent (QE) in $100 \mathrm{~g}$ of the extract. Calculations based on the calibration curve using the following linear equation:

$\mathrm{Y}=0.0012 \mathrm{x}+0.008\left(\mathrm{R}^{2}=0.944\right)$

\section{Antioxidant activity evaluation:}

\section{DPPH radical-scavenging assay:}

DPPH (1,1-diphenyl-2-picrylhydrazyl) activity of the obtained leaf extracts of each species of Moringa was measured according to Gülçin et al. (2004) by bleaching of the purple colored solution of DPPH $(0.1 \mathrm{mM})$ in ethanol and then $1.0 \mathrm{ml}$ of this solution was added to $3 \mathrm{ml}$ of each extract at different doses $(50-250 \mathrm{~g})$. The mixture was vigorously shaken and allowed to stand at room temperature for $30 \mathrm{~min}$. The absorbance of each sample was measured at $517 \mathrm{~nm}$ using UV spectrophotometer UK (Jenway-6405UV/VIS). The lower absorbance of the reaction mixture, the higher free radical scavenging activity is. The antioxidant activity was calculated as follows:

Antioxidant activity (inhibition \%) $=[(\mathrm{A}$ control - A sample) / A control] $\times 100$

where A control is the absorbance of the control (DPPH reagent) and A sample is the absorbance in the presence of extract.

\section{ABTS radical-scavenging assay:}

ABTS [2,2-azino-bis (3-ethylbenzthi azoline-6-sulphonic acid)] activity of the leaf extracts of each studied species was adopted according to Re et al. (1999) in which, the stock solutions were of $7 \mathrm{mM}$ ABTS and 2.4 $\mathrm{mM}$ potassium persulphate solutions. The working solution was then prepared by mixing the two stock solutions in equal quantities and allowing them to react for $12 \mathrm{~h}$ at room temperature in the dark. The solution was then diluted by mixing $1 \mathrm{ml}$ ABTS solution with $60 \mathrm{ml}$ of methanol to obtain an absorbance of $0.076 \pm 0.001$ units at $734 \mathrm{~nm}$. Plant extracts of $1.0 \mathrm{ml}$ at various concentrations $0.2-1.0 \mathrm{mg} / \mathrm{ml}$ of the extract were allowed to react with $1.0 \mathrm{ml}$ of ABTS 
solution, and the absorbance was measured at $734 \mathrm{~nm}$ after 7 min using spectrophotometer UK (Jenway-6405-UV/VIS). The ABTS scavenging capacity of the extract and percentage inhibition calculated as:

ABTS radical scavenging activity (\%) = [(Abs control - Abs sample)/(Abs control)] $\times 100$

where Abs control is the absorbance of ABTS + radical + methanol; Abs sample is the absorbance of ABTS+ radical + sample extract.

\section{High performance liquid chromatography assay (HPLC):}

\section{Standards:}

Working standards were made by diluting stock solutions in methanol to yield 2-4 $\mu \mathrm{g} / \mathrm{ml}$. Stock/working solution of the standards was stored in darkness at $-18{ }^{\circ} \mathrm{C}$ and they remained stable over 3 months.

- For quantification of phenolic compounds, the following standards were used: Gallic, pyrogallol, 4-amino benzoic, 3-OH tyrosol, protocatchuic, catehein, epicatechein, caffiene, P-OH benzoic, caffeic, vanillic, ferulic, iso-ferulic, reversetrol, ellagic, evanillic, alpha-coumaric, chlorogenic, catechol, benzoic, 3, 4, 5-methoxycinnamic, coumarin, salicylic, p-coumaric and cinnamic.

- For quantification of flavonoids, the following standards were used: Naringin, rutin, hisperdin, rosmarinic, quercetrin, quercetin, narengenin, kampherol, hispertin, apegenin and 7-OH flavone.

\section{Separation and quantification of phenolic compounds:}

Extraction, separation and quantification of phenolic compounds were determined by HPLC according to the method of Goupy et al. (1999) as follows: five grams of each sample of the three studied species of Moringa were mixed with methanol and centrifuged at $10000 \mathrm{rpm}$ for $10 \mathrm{~min}$. The supernatant was filtered through a $0.2 \mu \mathrm{m}$ Millipore membrane then $1-3 \mathrm{ml}$ was collected in a vial for injection in HPLC Hewllet Packared (series 1200) which was equipped with auto sampling injector, solvent degasser, ultraviolet (UV) detector set at 280 $\mathrm{nm}$ and quaternary HP pump (series 1100). The C18 reverse phase column temperature was maintained at $35{ }^{\circ} \mathrm{C}$. Gradient separation was carried out with methanol and acetonitrile as a mobile phase at flow rate of $1.0 \mathrm{ml} / \mathrm{min}$. Phenolic acid standards from Sigma Co. were dissolved in a mobile phase and injected into HPLC. Retention time and peak area were used to calculate the phenolic compounds concentration by the data analysis of HEWLLET Packared software.

\section{Separation and quantification of flavonoid compounds:}

Flavonoids were determined by HPLC according to the method of Pirjo et al. (2000) as follows: $0.5 \mathrm{~g}$ of each sample leaves of the three studied species of Moringa were mixed with $40 \mathrm{ml}$ (62.5\% aqueous) methanol containing $2 \mathrm{~g} / \mathrm{l}$ of 2, (3)-tert-butyl-4hydroxyanisole (BHA). The mixture was then ultrasonicated for $5 \mathrm{~min}$. To this extract, $10 \mathrm{ml}$ of $6 \mathrm{M}$ HCL were added. The sample was bubbled with nitrogen for 40-60 sec then the flask was tightly sealed. Hydrolysis was carried out in a shaking water bath at $90^{\circ} \mathrm{C}$ for $2 \mathrm{~h}$. After hydrolysis, the sample was allowed to cool, then it was filtered, made up to 100 ml with methanol, and ultrasonicated for 5 min. Before quantification by HPLC, the sample was filtered through a $0.2 \mu \mathrm{m}$ Millipore membrane. Ten microliter of sample were collected in a vial for injection in HPLC Hewllet Packared (series 1200) which equipped with auto sampling injector, solvent degasser, ultraviolet (UV) detector set at 330 nm and quaternary HP 1090M Series II diode array and an eight channel electrochemical coulometric array detector (EC;Esa Inc., USA). The C18 guard column temperature was maintained at $35^{\circ} \mathrm{C}$. Gradient separation was carried out with $50 \mathrm{mM} \mathrm{H}_{3} \mathrm{PO}_{4}, \mathrm{pH} 2.5$ (solution A) and acetonitrile (solution B) as a mobile phase at flow rate of $0.7 \mathrm{ml} / \mathrm{min}$. Ten microliter of the flavoniod standards from Sigma Co. were also dissolved in a mobile 
phase and injected into HPLC. All flavonoids were quantified using the external standard method which was based on peak area (DAD) or peak height (EC).

\section{Data analysis:}

Data of leaves (yield extract, total phenolic compounds, total flavonoids, DPPH and ABTS radical-scavenging assays) were statistically analyzed using a factorial analysis of variance (ANOVA), in a completely randomized design analysis according to the procedure outlined by Sendecor and Cochran (1981). Means were compared by multiple range tests using the Statistical Package for the Social Science (SPSS) version 10 and Duncan's multiple range tests were according to Duncan (1955) at probability $5 \%$.

\section{RESULTS}

Basic investigations of the extracts for their major phytocompounds are vital because, the active principles of many drugs are these secondary metabolites found in plants. Three different extracts (hexane, ethyl acetate and ethanol 70\%) of three Moringa species leaves were investigated for their antioxidant activity and for detecting total phenolic compounds and flavonoids included.

\section{Leaf yield extracts:}

The yield of leaf extracts of the three Moringa species showed that $M$. peregrina produced the highest yield extract with all solvents especially with ethanol 70\% (35 g/100 g) followed by $M$. stenopetala ethanol extract (33 g/100 g) and then M. oleifera (29 g/100 g) with the same extract. Hexane was the lowest solvent to yield extract and even though $M$. peregringa (6 g/100 g) exceeded the other two species ( 5 and $4 \mathrm{~g} / 100 \mathrm{~g}$ ) for $M$. stenopetala and $M$. oleifera, respectively as illustrated in Table (1) and Fig. (1).

\section{Total phenolic compounds content:}

Results revealed that the highest phenolic content was obtained by $70 \%$ ethanol extract of the three studied species. In the case of $70 \%$ ethanol extract, $M$. peregrina exhibited, relatively, the highest phenolic content (11.66 g GAE/100 g) followed by M. oleifera (10 g GAE/100 g) then $M$. stenopetala (9.68 $\mathrm{g}$ GAE/100 g). Even though, hexane extract was the lowest solvent to show up total phenolic compounds in the three Moringa species, except that for $M$. peregrina that recorded the highest content (5.34 g GAE/100 g) among other two species. Ethyl acetate extract of $M$. peregrina leaves exhibited a content of phenolic compounds as $6.8 \mathrm{~g}$ GAE/100 g which exceeded the other two species in the same extract as illustrated in Table (2) and Fig. (2).

\section{Total flavonoids content:}

Data presented in Table (3) demonstrated that the highest total flavonoid content was obtained by hexane extract of leaves of the three investigated species of Moringa. $M$. peregrina showed relatively the highest flavonoids content (7.21 g QE/100 g) followed by $M$. stenopetala (6.45 g QE/100 g) and then $M$. oleifera (6.28 g QE/100 g) with the same extract. Regarding ethanol (70\%) extracts, they exhibited the lowest contents of flavonoids and $M$. peregrina was the highest (4.52 g QE/ 100 g) among other two species. Ethyl acetate extracts of the three studied species were with the following order in their flavonoids content: $M$. peregrina (5.7 g $\mathrm{QE} / 100 \mathrm{~g})>$ M. stenopetala (5.3 g QE/100 g) $>$ M. oleifera (5.1 g QE/100 g) (Fig., 3).

\section{2,2-Diphenyl-1-picryl hydrazyl radical- scavenging assay (DPPH):}

DPPH scavenging activity assay has been utilized to attain the understanding of antioxidant potentials. The inhibition percentages of DPPH scavenging activity in all leaves extracts were dose-dependent. Data revealed that, the more increment in solvent concentration (250, 500 and $1000 \mu \mathrm{g} / \mathrm{ml})$, the more inhibition of DPPH occurs. Generally, results of Table (4) exposed that, 70\% ethanol leaf extracts of the three studied species presented the highest DPPH scavenging potency followed by hexane then ethyl acetate extracts. It was noticed that, $M$. peregrina was the highest species to inhibit DPPH as $97 \%$ with $1000 \mu \mathrm{g} / \mathrm{ml}$ ethanol $70 \%, 88 \%$ with 1000 
Table 1. Effect of the interaction between extraction solvents and Moringa species on yield extract (g/100 g).

\begin{tabular}{cccc}
\hline Extraction solvents & M. stenopetala & M. peregrina & M. oleifera \\
\hline Hexane & $5.00 \mathrm{~d}$ & $6.00 \mathrm{~d}$ & $4.00 \mathrm{~d}$ \\
Ethyl acetate & $8.00 \mathrm{~cd}$ & $11.00 \mathrm{c}$ & $7.00 \mathrm{~cd}$ \\
Ethanol 70\% & $33.00 \mathrm{ab}$ & $35.00 \mathrm{a}$ & $29.00 \mathrm{~b}$
\end{tabular}

Means followed by the same letter(s) are not significantly different according to Duncan's multiple range test.

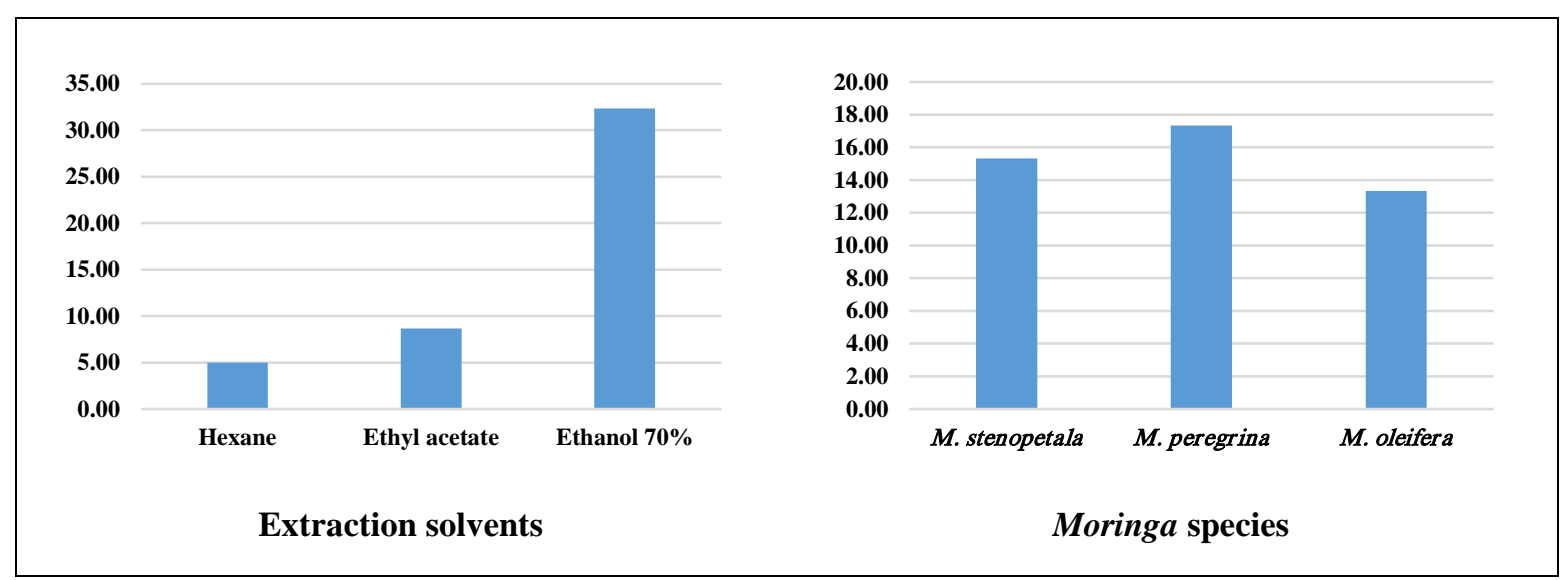

Fig. 1. Effect of extraction solvents and Moringa species on yield extract (g/100g).

Table 2. Effect of the interaction between extraction solvents and Moringa species on total phenolic acids ( $\mathrm{g}$ GAE/100 g extract) in Moringa leaf extracts.

\begin{tabular}{cccc}
\hline Extracts & M. stenopetala & M. peregrina & M. oleifera \\
\hline Hexane & $4.32 \mathrm{c}$ & $5.34 \mathrm{c}$ & $4.87 \mathrm{c}$ \\
Ethyl acetate & $6.40 \mathrm{c}$ & $6.80 \mathrm{bc}$ & $5.87 \mathrm{c}$ \\
Ethanol 70\% & $9.68 \mathrm{ab}$ & $11.66 \mathrm{a}$ & $10.00 \mathrm{a}$ \\
\hline
\end{tabular}

Means followed by the same letter(s) are not significantly different according to Duncan's multiple range test.

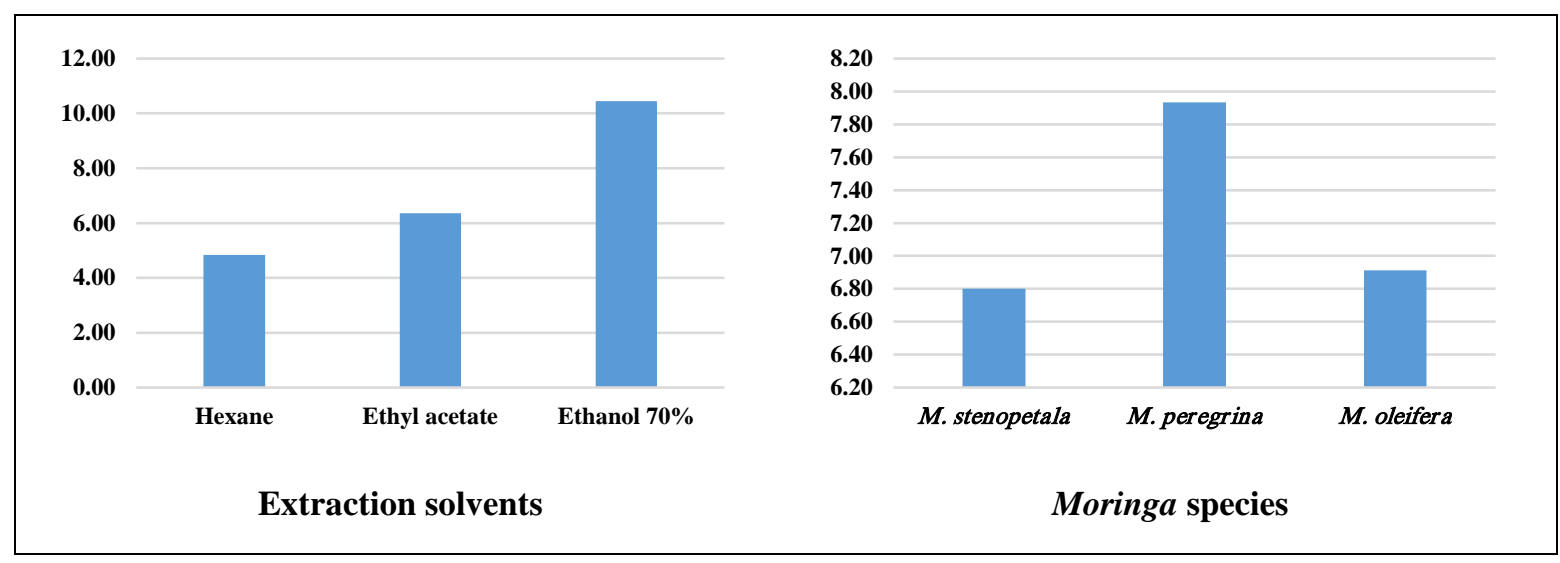

Fig. 2. Effect of extraction solvents and Moringa species on total phenolic acids (g GAE/100 g extract) in Moringa leaf extracts. 
Table 3. Effect of the interaction between extraction solvents and Moringa species on total flavonoids (g QE/100 g extract) in Moringa leaf extracts.

\begin{tabular}{cccc}
\hline Extraction solvents & M. stenopetala & M. peregrina & M. oleifera \\
\hline Hexane & $6.45 \mathrm{ab}$ & $7.21 \mathrm{a}$ & $6.28 \mathrm{ab}$ \\
Ethyl acetate & $5.30 \mathrm{a}-\mathrm{c}$ & $5.70 \mathrm{a}-\mathrm{c}$ & $5.10 \mathrm{a}-\mathrm{c}$ \\
Ethanol 70\% & $3.28 \mathrm{c}$ & $4.52 \mathrm{bc}$ & $3.12 \mathrm{c}$ \\
\hline
\end{tabular}

Means followed by the same letter(s) are not significantly different according to Duncan's multiple range test.

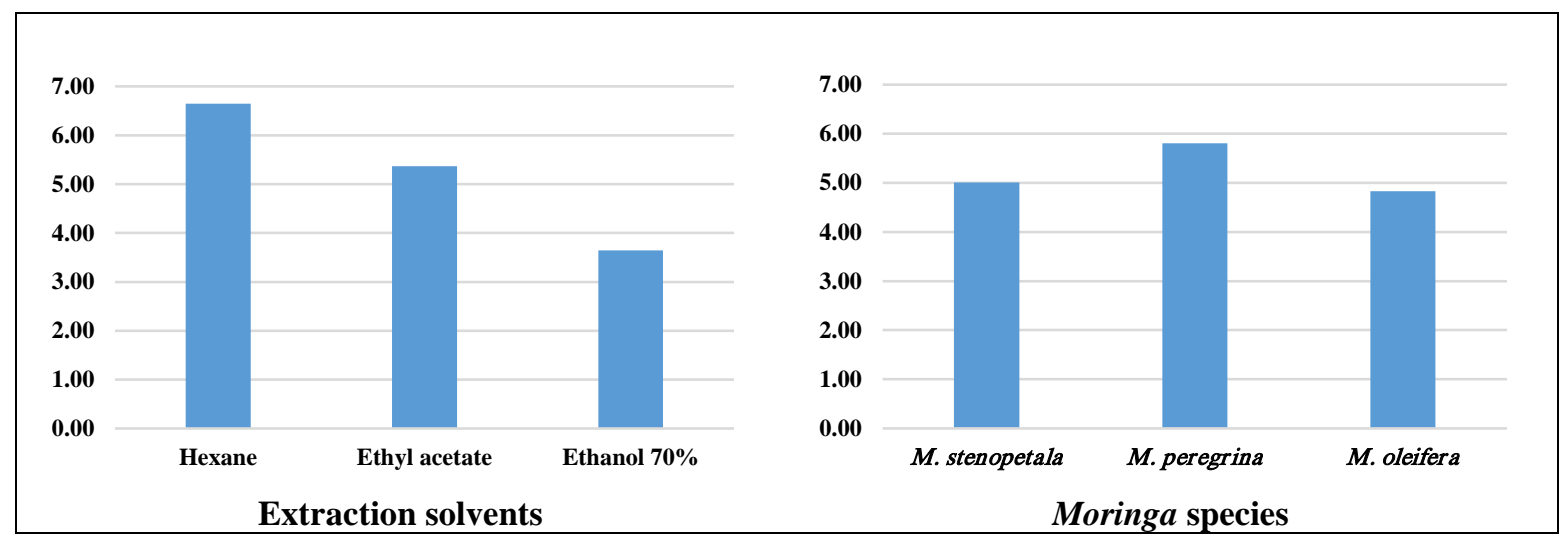

Fig. 3. Effect of extraction solvents and Moringa species on total flavonoids (g QE/100 g extract) in Moringa leaf extracts.

Table 4. DPPH-assay (\% inhibition) of Moringa leaf extracts as affected by the interaction between extraction solvents and Moringa species.

\begin{tabular}{|c|c|c|c|}
\hline Extraction solvents & M. stenopetala & M. peregrina & M. oleifera \\
\hline Ethanol $(250$ pg/ml) & 85.00 e & $91.00 \mathrm{~b}$ & $80.00 \mathrm{f}$ \\
\hline Ethanol $(500 \mu \mathrm{g} / \mathrm{ml})$ & 86.00 de & $96.00 \mathrm{a}$ & $82.00 \mathrm{f}$ \\
\hline Ethanol $(1000 \mu \mathrm{g} / \mathrm{ml})$ & $89.00 \mathrm{bc}$ & $97.00 \mathrm{a}$ & 86.00 de \\
\hline Hexane $(250 \mu \mathrm{g} / \mathrm{ml})$ & $65.00 \mathrm{ij}$ & $68.00 \mathrm{~h}$ & $55.00 \mathrm{k}$ \\
\hline Hexane $(500 \mu \mathrm{g} / \mathrm{ml})$ & $76.00 \mathrm{~g}$ & $76.00 \mathrm{~g}$ & 67.00 hi \\
\hline Hexane $(1000 \mu \mathrm{g} / \mathrm{ml})$ & $82.00 \mathrm{f}$ & $88.00 \mathrm{~cd}$ & $75.00 \mathrm{~g}$ \\
\hline Ethyl acetate $(250 \mu \mathrm{g} / \mathrm{ml})$ & $35.00 \mathrm{n}$ & $40.00 \mathrm{~m}$ & $20.00 \mathrm{p}$ \\
\hline Ethyl acetate $(500 \mu \mathrm{g} / \mathrm{ml})$ & $42.00 \mathrm{~lm}$ & $55.00 \mathrm{k}$ & 30.00 o \\
\hline Ethyl acetate $(1000 \mu \mathrm{g} / \mathrm{ml})$ & $56.00 \mathrm{k}$ & $64.00 \mathrm{j}$ & 44.001 \\
\hline
\end{tabular}

Means followed by the same letter(s) are not significantly different according to Duncan's multiple range test.

$\mu \mathrm{g} / \mathrm{ml}$ hexane and $64 \%$ with $1000 \mu \mathrm{g} / \mathrm{ml}$ ethyl acetate. $M$. stenopetala was higher than $M$. oleifera in DPPH scavenging activity with the three concentrations of $70 \%$ ethanol, hexane and ethyl acetate. Different concentrations of ethyl acetate extract showed the lowest inhibition of DPPH in the leaves of the studies species as illustrated in Fig. (4).
5. 2,2-azino-bis (3-ethylbenzothiazoline-6sulfonate) radical-scavenging assay (ABTS)

According to results shown in Table (5), the maximum inhibition of ABTS was recorded for $70 \%$ ethanol leaf extract followed by hexane then ethyl acetate extract. 


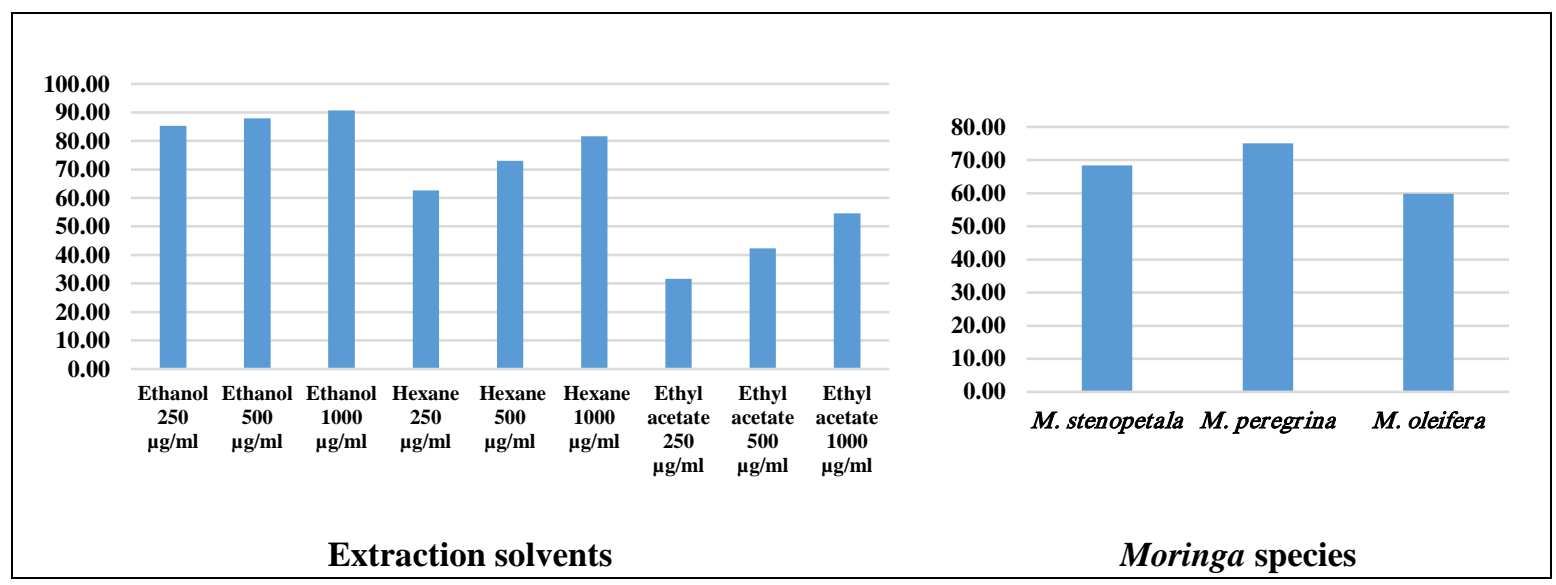

Fig. 4. DPPH-assay (\% inhibition) of Moringa leaf extracts as affected by extraction solvents and Moringa species.

Table 5. ABTS-assay (\% inhibition) of Moringa leaf extracts as affected by the interaction between extraction solvents and Moringa species.

\begin{tabular}{cccc}
\hline Extraction solvents & M. stenopetala & M. peregrina & M. oleifera \\
\hline Ethanol $(\mathbf{2 5 0} \mathbf{\mu g} / \mathbf{m l})$ & $80.00 \mathrm{a}-\mathrm{d}$ & $85.60 \mathrm{a}-\mathrm{c}$ & $79.00 \mathrm{a}-\mathrm{d}$ \\
Ethanol $(\mathbf{5 0 0} \mathbf{~} \mathbf{g} / \mathbf{m l})$ & $85.70 \mathrm{a}-\mathrm{c}$ & $87.69 \mathrm{a}-\mathrm{c}$ & $82.00 \mathrm{a}-\mathrm{d}$ \\
Ethanol $(\mathbf{1 0 0 0} \mathbf{~} \mathbf{g} / \mathbf{m l})$ & $90.23 \mathrm{ab}$ & $92.67 \mathrm{a}$ & $89.00 \mathrm{a}-\mathrm{c}$ \\
Hexane $(\mathbf{2 5 0} \mathbf{~} \mathbf{g} / \mathbf{m l})$ & $58.00 \mathrm{e}-\mathrm{h}$ & $62.00 \mathrm{e}-\mathrm{g}$ & $52.00 \mathrm{f}-\mathrm{i}$ \\
Hexane $(\mathbf{5 0 0} \mathbf{~} \mathbf{g} / \mathbf{m l})$ & $69.00 \mathrm{de}$ & $73.00 \mathrm{c}-\mathrm{e}$ & $62.00 \mathrm{e}-\mathrm{g}$ \\
Hexane $(\mathbf{1 0 0 0} \mathbf{~} \mathbf{g} / \mathbf{m l})$ & $80.00 \mathrm{a}-\mathrm{d}$ & $83.00 \mathrm{a}-\mathrm{d}$ & $74.00 \mathrm{~b}-\mathrm{e}$ \\
Ethyl acetate $(\mathbf{2 5 0} \mathbf{~} \mathbf{g} / \mathbf{m l})$ & $38.00 \mathrm{ij}$ & $44.00 \mathrm{hi}$ & $25.00 \mathrm{j}$ \\
Ethyl acetate $(\mathbf{5 0 0} \mathbf{~} \mathbf{g} / \mathbf{m l})$ & $45.00 \mathrm{hi}$ & $52.00 \mathrm{f}-\mathrm{i}$ & $37.00 \mathrm{ij}$ \\
Ethyl acetate $(\mathbf{1 0 0 0} \mathbf{~} \mathbf{g} / \mathbf{m l})$ & $62.00 \mathrm{e}-\mathrm{g}$ & $67.00 \mathrm{~d}-\mathrm{f}$ & $49.00 \mathrm{~g}-\mathrm{i}$ \\
\hline
\end{tabular}

Means followed by the same letter(s) are not significantly different according to Duncan's multiple range test.

There was increase in ABTS radical scavenging activity with the increase in concentration of the different solvent leaves extract used in this study from 250 up to 1000 $\mu \mathrm{g} / \mathrm{ml}$. Similarly, it was the concentration of $1000 \mu \mathrm{g} / \mathrm{ml}$ of each solvent that yielded the highest ABTS inhibition percentages. In the same way in DPPH assay, the inhibition percentage of ABTS radical by the studied species leaf extracts was dose-dependent. $M$. peregrina was the highest species to inhibit ABTS as $92.67 \%$ with $1000 \mu \mathrm{g} / \mathrm{ml}$ ethanol $70 \%, 83 \%$ with $1000 \mu \mathrm{g} / \mathrm{ml}$ hexane and $67 \%$ with $1000 \mu \mathrm{g} / \mathrm{ml}$ ethyl acetate. In this respect, $M$. stenopetala was higher than M. oleifera in ABTS scavenging activity with the three concentrations of (70\%) ethanol, hexane and ethyl acetate. The different concentrations of ethyl acetate extract showed the lowest inhibition of ABTS in the leaves of the studies species Fig. (5).

\section{High Performance Liquid Chroma- tography assay (HPLC):}

\section{a. Phenolic compounds detection in three Moringa species leaf extracts:}

Twenty-five phenolic acid compounds were detected, identified and quantified according to their retention time and the spectral characteristics of their peaks compared with standards, as well as, by spiking the sample with individual standards in each leaf sample of the three studied Moringa species. Quantitative HPLC analysis of the three studied species showed higher content of bioactive compounds in their 


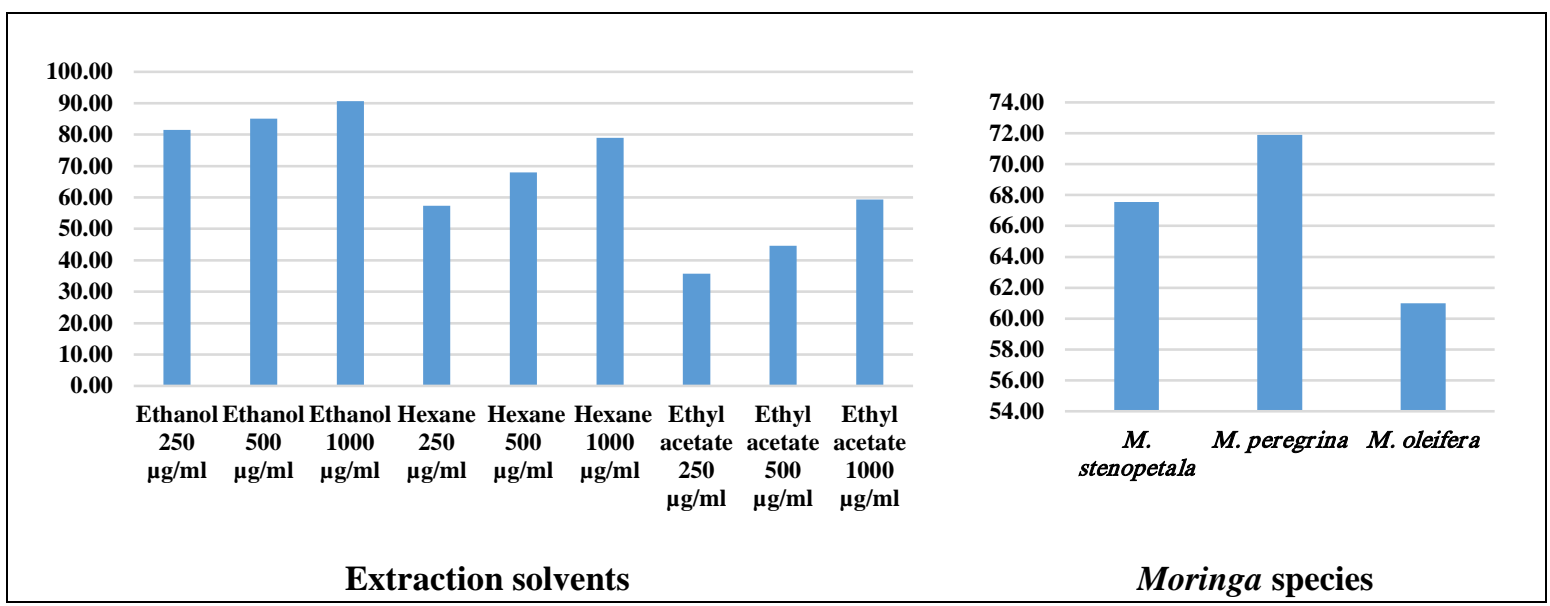

Fig. 5. ABTS-assay (\% inhibition) of Moringa leaf extracts as affected by extraction solvents and Moringa species.

leaves. Out of the 25 phenolic acids, 3-OH tyrosol was the dominant compound (1339.29 ppm) in $M$. oleifera leaves. Four phenolic compounds namely pyrogallol, catechol, evanillic and benzoic were expected to be the most abundant in the leaves of the three Moringa species. Their values differed according to the species as follows: pyrogallol was the highest in $M$. peregrina (432.60 ppm) followed by $M$. stenopetala (417.50 ppm) and then $M$. oleifera (234.36 ppm). Both of catechol and benzoic were the highest in $M$. stenopetala (316.60 and $432.77 \mathrm{ppm}$, respectively) followed by $M$. oleifera (274.29 and $184.14 \mathrm{ppm}$ ) and then $M$. peregrina (227.89 and $115.45 \mathrm{ppm}$ ). E-vanillic was highly recorded for $M$. stenopetala leaves (422.95 ppm) followed by $M$. peregrina leaves (349.06 ppm) and then $M$. oleifera leaves (261.01 ppm) as shown in Table (6). Gallic, protocatechuic, catechin and caffeic acids showed highest values in $M$. peregrina (13.95, 68.03, 150.89 and 24.19 ppm) followed by $M$. stenopetala $(6.50,13.05$, 42.17 and $10.33 \mathrm{ppm}$ ) and then M. oleifera (5.36, 10.76, 37.64 and $5.89 \mathrm{ppm}$ ), respectively. Ferulic, resveratrol, alphacoumaric and cinnamic acids represented an order of phenolic values as $M$. oleifera $>M$. stenopetala $>M$. peregrina as follows: (14.67, 13.98 and $9.50 \mathrm{ppm}),(120.16,52.71$ and $3.00 \mathrm{ppm}),(7.52,1.45$ and $0.83 \mathrm{ppm})$ and (37.77, 33.70 and $23.16 \mathrm{ppm}$ ) for the three species, respectively (Table, 6).
Moreover, $M$. oleifera exceeded both $M$. peregrina and $M$. stenopetala in three phenolic compounds namely, 4-amino benzoic (5.71, 4.25 and $3.88 \mathrm{ppm})$, pcoumaric (12.01, 6.88 and $3.86 \mathrm{ppm})$ and salicylic acid (76.36, 37.60 and $24.96 \mathrm{ppm}$ ), respectively (Table, 6). Although coumarin was identified in $M$. stenopetala (8.33 ppm) and $M$. peregrina (2.62 $\mathrm{ppm})$ but it was not detected in $M$. oleifera leaves. Likewise, data revealed higher phenolics in $M$. stenopetala followed by $M$. peregrina then $M$. oleifera in each of epicatechein, caffeine and iso-ferulic contents (64.24, 62.41 and $24.23 \mathrm{ppm})$, (34.86, 22.53 and $8.13 \mathrm{ppm})$ and (29.22, 10.66 and $9.32 \mathrm{ppm})$, respectively. Furthermore, it exceeded $M$. oleifera and $M$. peregrina in their content of chlorogenic and 3,4,5methoxy-cinnamic acids (443.94, 317.29 and $91.69 \mathrm{ppm}$ ) and (9.61, 7.37 and $4.23 \mathrm{ppm}$ ), respectively (Table, 6$)$. Finally, $M$. peregrina seemed to possess higher $\mathrm{P}-\mathrm{OH}$ benzoic, vanillic and ellagic acid contents than M. oleifera and M. stenopetala (139.17, 69,18 and $62.91 \mathrm{ppm}),(29.97,26.47$ and $21.29 \mathrm{ppm}$ ) and (54.42, 31.99 and $26.64 \mathrm{ppm})$ for each phenolic acid, respectively (Table, $6)$.

\section{b. Flavonoids detection in three Moringa species leaf extracts:}

HPLC was used in determinations and the external standards enabled the identification of 11 flavonoid compounds in the leaves of the three studied species of 
Table 6. Bioactive phenolic compounds in three Moringa species leaves extract evaluated by HPLC.

\begin{tabular}{cccc}
\hline Phenolic compounds (ppm) & M. peregrina & M. stenopetala & M. oleifera \\
\hline Gallic & 13.95 & 6.50 & 5.36 \\
Pyrogallol & 432.60 & 417.50 & 234.36 \\
4-Amino benzoic & 4.25 & 3.88 & 5.71 \\
3-OH Tyrosol & 193.06 & 104.13 & 1339.29 \\
Protocatechuic & 68.03 & 13.05 & 10.76 \\
Catechin & 150.89 & 42.17 & 37.64 \\
Chlorogenic & 91.69 & 443.94 & 317.29 \\
Catechol & 227.89 & 316.60 & 274.29 \\
Epicatechein & 62.41 & 64.24 & 24.23 \\
Caffeine & 22.53 & 34.86 & 8.13 \\
P-OH benzoic & 139.17 & 62.91 & 69.18 \\
Caffeic & 24.19 & 10.33 & 5.89 \\
Vanillic & 29.97 & 21.29 & 26.47 \\
Ferulic & 9.50 & 13.98 & 14.67 \\
Iso-ferulic & 10.66 & 29.22 & 9.32 \\
Resveratrol & 3.00 & 52.71 & 120.16 \\
Ellagic & 54.42 & 26.64 & 31.99 \\
E-vanillic & 349.06 & 422.95 & 261.01 \\
Alpha-coumaric & 0.83 & 1.45 & 7.52 \\
Benzoic & 115.45 & 432.77 & 184.14 \\
3,4,5-methoxy-cinnamic & 4.23 & 9.61 & 7.37 \\
Coumarin & 2.62 & 8.33 & 0.00 \\
Salicylic & 37.60 & 24.96 & 76.36 \\
P-coumaric & 6.88 & 3.86 & 12.01 \\
Cinnamic & 23.16 & 33.70 & 37.77 \\
\hline & & &
\end{tabular}

Table 7. Bioactive flavonoids in the three Moringa species leaves extract evaluated by HPLC.

\begin{tabular}{cccc}
\hline Flavonoid compounds (ppm) & M.peregrina & M. stenopetala & M. oleifera \\
\hline Naringin & 22.93 & 40.77 & 53.61 \\
Rutin & 1200.06 & 804.45 & 340.79 \\
Hesperidin & 195.52 & 1191.97 & 3846.97 \\
Rosmarinic & 3.95 & 290.57 & 53.39 \\
Quercetrin & 38.77 & 197.56 & 66.44 \\
Quercetin & 1.71 & 5.19 & 10.06 \\
Naringenin & 0.46 & 2.08 & 2.57 \\
Kaempferol & 3.36 & 8410.12 & 5.61 \\
Hispertin & 3.81 & 16.98 & 11.35 \\
Apigenin & 0.52 & 4.26 & 3.92 \\
OH flavone-7 & 1.70 & 5.90 & 3.37 \\
\hline
\end{tabular}

Moringa. Results presented in Table (7) showed that kaempferol was the dominant flavonoid detected in $M$. stenopetala leaves (8410.12 ppm) followed by M. oleifera (5.61 ppm) and (3.36 ppm) in M. peregrina. Rutin values were (1200.06, 804.45 and 340.79 ppm) in $M$. peregrina, $M$. stenopetala and $M$. oleifera respectively. $M$. stenopetala showed higher rosmarinic, quercetrin, hispertin, apigenin and $7-\mathrm{OH}$ flavone content of 
(290.57, 197.56, 16.98, 4.26 and $5.90 \mathrm{ppm})$ than $M$. oleifera (53.39, 66.44, 11.35, 3.92 and $3.37 \mathrm{ppm})$ and $M$. peregrina $(3.95,38.77$, 3.81, 0.52 and $1.70 \mathrm{ppm})$. As shown in Table (7), M. oleifera possessed higher naringin, naringenin, hesperidin and quercetin content (53.61, 2.57, 3846.97 and $10.06 \mathrm{ppm}$ ) than $M$. stenopetala (40.77, 2.08, 1191.97 and 5.19 ppm) and $M$. peregrina (22.93, 0.46, 195.52 and1.71 ppm).

\section{DISCUSSION}

The effect of antioxidants on DPPH radical scavenging is thought to be due to their hydrogen donating ability and this model of scavenging is a widely used method to evaluate antioxidant activities in a relatively short time compare to other methods (Soares et al., 1997). In the DPPH assay, the scavenging action may be due to the hydrogen donating ability, whereas scavenging of ABTS radical is due to scavenging of proton radicals induced through donation of electrons (Chu et al., 2010). It was obvious that the total phenolic compounds content measured by the Folin-Ciocalteu's procedure did not give a full picture of the quantity or quality of the phenolic constituents in the extracts due to some interference rising from other chemical components present in the extract Kahkonen et al. (1999).

The results of our preliminary chemical investigations confirmed the presence of various classes of bioactive chemical constituents in the different extracts of the three Moringa species leaves including phenolic compounds and flavonoids. Flavonoids are considered to be one of the most promising polyphenolic compounds among plant secondary metabolites. Therefore, based on the phytochemical screening results, the total phenolic and flavonoid contents of the different extracts of the three Moringa species leaves were estimated and also their antioxidant potential was investigated by in vitro DPPH and ABTS assay methods.

Regarding the revealed results, it was obvious that ethanol (70\%) was the best solvent to extract the highest leaf yield of the three Moringa species followed by ethyl acetate and then hexane. Additionally, $M$. peregrina was the richest species followed by $M$. stenopetala then $M$. oleifera.

Based on results of the current study, it was clear that, leaf ethanol (70\%) extract of $M$. peregrina has the highest noticeable total phenolic compounds (11.66 g GAE/100 g) followed by its ethyl acetate extract then hexane extract. Hexane was the best to extract the highest flavonoids content in $M$. peregrina (7.21 g QE/100 g) followed by its ethyl acetate extract then ethanol (70\%).

In contrast, Al-Owaisi et al. (2014) did not detect any phenolic compounds nor flavonoids in $M$. peregrina leaf hexane extract. They reported their presence in ethyl acetate extract only which were higher than our obtained results.

Furthermore, $M$. peregrina leaves exhibited the richest phenolic compounds and flavonoid contents as well. Ethanol extract of $M$. oleifera leaves showed higher phenolic compounds and flavonoids content than that reported by Jonathan et al. (2012). M. oleifera leaves, in our study showed higher phenolic content than what reported by Leone et al. (2015) who used $80 \%$ ethanol extract and obtained $8.21 \mathrm{~g} / 100 \mathrm{~g}$, while in contrast, our results were less than theirs in the flavonoid content with the same solvent (5.31 g/100 gm).

Our study on $M$. oleifera leaves was supported by Maqsood et al. (2017) regarding the ethanol extract in phenolic compound determination and the moderate action of ethyl acetate extract but also contradicted them for the hexane extract since they did not exhibit any phenolic compounds or flavonoids.

In addition, our data are exactly the same like that of Tekle et al. (2015) in the DPPH scavenging activity of $M$. oleifera leaves with ethanol $70 \%$ which showed $81.45 \%$ with the concentration of $300 \mu \mathrm{g} / \mathrm{ml}$ but we were higher than them in the total phenolic compounds content. Conversely, the present 
results on the total phenolic compounds content contradicted what mentioned by Vongsak et al. (2013) with ethanol 70\% of $M$. oleifera leaves extract which was higher (13.23 g CLA/100 gm) than ours and total flavonoids content (6.2 g IQ /100 gm) which was also higher than ours. In the same study, our DPPH was higher than theirs (62.94\%) and their yield was higher than ours.

In another study of Leelavinothan et al. (2007) showed that total phenolic compounds in $M$. oleifera leaves as $118 \mathrm{mg} / \mathrm{g}$ and a strong reducing power of DPPH radical scavenging activity that support our results along with those of Wangcharoen and Gomolmanee (2011). Using different extracts as in Shih et al. (2011) and Rajput et al. (2017) investigations also associated our findings on the reducing power of these extracts on ABTS and DPPH which revealed also high contents of total phenolic compounds in M. oleifera leaves.

For M. stenopetala leaves, it was also boosted by Geleta et al. (2016) observations that it contains high different classes of secondary metabolites when extracted with $70 \%$ ethanol while $M$. peregrina leaves methanol extract showed the same reducing power on DPPH assay as $8.06 \mu \mathrm{g} / \mathrm{ml}$ in Afsharypuor (2012) studies which was less than our results. The DPPH radicalscavenging assay revealed high reducing power in the present approach with $M$. stenopetala leaves which was advocated by Habtemariam (2015) and Toma et al. (2014) with different extracts.

The results of antioxidant activity of the extracts expressed in percentage DPPH and ABTS activities are presented in this study. Regarding the three studied species, the scavenging effect of the three Moringa species leaves on the DPPH radical decreased in the order of $M$. peregrina $>M$. stenopetala $>$ M. oleifera at the concentration order of $1000 \mu \mathrm{g} / \mathrm{ml}>500 \mu \mathrm{g} / \mathrm{ml}>250 \mu \mathrm{g} / \mathrm{ml}$, respectively with the extracts order of ethanol $(70 \%)>$ hexane $>$ ethyl acetate respectively. With ABTS model, it was the same order as in DPPH assay in the leaves antioxidant activity determination. Our results on $M$. oleifera leaf ethanol extract were greater than those of Jonathan et al. (2012) who showed $167.25 \mu \mathrm{g} / \mathrm{ml}$ with DPPH radical and Falowo et al. (2017) who revealed percentage inhibition of DPPH radicals as $75.9 \%$ while its ABTS radicals was $82.8 \%$.

In general view, with increasing in solvent polarity, total phenolic compounds and total flavonoids content also increased in the extracts and likewise, no significant correlations between the total phenolic content and antioxidant activity of the plant extracts that different phenolic compounds have different responses in the FolinCiocalteu method (Statue-Gracia et al., 1997). Thus, the antioxidant activity of an extract cannot be predicted on the basis of its total phenolic content.

For better understanding the phenolic nature and the association of flavonoids and phenolic compounds intake and health outcomes, their phytochemical analysis using HPLC analysis was performed to identify and to determine the major classes of compounds present in methanolic leaf extracts of the studied species of Moringa.

The results of the present approach confirmed that $M$. stenopetala was the best to reveal the highest contents of flavonoids in the leaves. $M$. stenopetala exceeded other two species in the HPLC analysis in both phenolic and flavonoid compounds. However, $M$. stenopetala leaves exceeded the other two species in its chlorogenic (443.94 ppm), catechol (316.6 ppm), e-vanillic (422.95 ppm) and benzoic (432.77 ppm) content while $M$. oleifera showed the highest $3-\mathrm{OH}$ tyrosol content (1339.29 ppm). On the other hand, the current data revealed that rutin and hesperidin were the highest flavonoids detected in the leaves of the three species. M. oleifera yielded the highest hesperidin content (3846.97 ppm) while $M$. stenopetala yielded the highest kaempferol content (8410.12 ppm).

Rutin content was the highest in $M$. peregrina leaves which was comparable to a previous study of Afsharypour et al. (2012) 


\section{Shams R. Abo El-Fadl et al.}

while alternatively, our study was in agreement with Solomon and George (2015) about rutin content in $M$. stenopetala leaves which exceeded its content in $M$. oleifera leaves.

In general view, flavonoids were the principal phenolic compounds in M. oleifera leaves and its content of naringin, hisperdin, quercetin and narengenin was the highest among the studied species and that was supported by the study of Leone et al.(2015) who investigated the first presence of salicylic and ferulic acids in $M$. oleifera leaves and detected flavonoid deriving from kaempferol and quercetin. In this concern, Atawodi et al. (2010) also reported the presence of chlorogenic acid, rutin, quercetinglucoside, and kaempferol rhamnoglucoside in the methanol extract of $M$. oleifera leaves. Also, Mbikay (2012) revealed the presence of some major phenolic compounds such as gallic, caffeic, coumaric, salicylic, benzoic, cinnamic, chlorogenic acids in $M$. oleifera leaves. On the other hand, Ramesh et al. (2016) revealed the presence of quercetin, apigenin, and kaempferol in M.oleifera leaves who claimed that the Asian varieties exceeded the African ones.

The present results are close to those of Rodríguez-Pérez et al. (2015) who characterized 59 phenolic acid derivatives and flavonoids which being the most abundant in M. oleifera leaves and 30 of them were identified for the first time.

The previous phytochemical investigations of Singh et al.(2009) and Verma et al.(2009) have also coped with ours to identify seven flavonols in $M$. oleifera leaves including gallic acid, chlorogenic acid, rutin, ellagic acid, ferulic acid, quercetin, and kaempferol; however, only quercetin, kaempferol, gallic acid, and chlorogenic acid were found in all studies. Our results are consistent with those from previous studies, which showed the presence of gallic acid, chlorogenic acid, rutin, quercetin, kaempferol and apigenin in M. oleifera leaves as ValdezSolana et al. (2015) who revealed values higher than ours.

\section{Conclusion:}

The present study revealed phenolic and flavonoid spectrum of valuable medicinally plant (Moringa) with its three species which showed high contents and indicated that these compounds contribute to the antioxidant activity. According to results of this investigation, the three Moringa species can be regarded as promising plant species for natural plant sources of antioxidants with high potential value for drug preparation. Further detailed in vitro and in vivo correlation studies along with isolation of active constituents are needed to unravel novel treatment strategies for free radical induced diseases.

\section{REFERENCES}

Afsharypuor, S.; Wink, M.; Asghari, G.; Dehshahri, S. and Mohagheghzadeh, A. (2012). Antioxidant activity of methanolic leaf extract of Moringa peregrina (Forssk.) Fiori. Res Pharm Sci., 7(2):111118.

Akbar, S. and Al-Yahya, M.A. (2011). Screening of Saudi plants for phytoconstituents, pharmacological and antimicrobial properties. Australian Journal of Medical Herbalism, 23(2):7687.

Al-Kahtani, H.A. (1995). Some antinutritional factors in Moringa peregrina (Al-Yassar or Al-Ban) and soybean products. J. King Saud Univ., 7(1):31-4.

Al-Owaisi, M.; Al-Hadiwi, N. and Khan, S.A. (2014). GC-MS analysis, determination of total phenolics, flavonoid content and free radical scavenging activities of various crude extracts of Moringa peregrina (Forssk.) Fiori leaves. Asian Pacific Journal of Tropical Biomedicine, 4(12):964-970.

Anwar, F.S.; Latif, M.; Ashraf, M. and Gilani, A.H. (2007). Moringa oleifera: A food plant with multiple medicinal uses. Phytoth. Res., 21:17-25. 
AOAC (2000). Official Methods of Analysis. $17^{\text {th }}$ ed. Association of Official Analytical Chemists, Arlington, VA.

Atawodi, S.E.; Atawodi, J.C.; Idakwo, G.A.; Pfundstein, B.; Haubner, R.; Wurtele, G.; Bartsch, H. and Owen, R.W. (2010). Evaluation of the polyphenol content and antioxidant properties of methanol extracts of the leaves, stem, and root barks of Moringa oleifera Lam. J. Med. Food, 13:710-716.

Chang, L.W.; Yen, W.J.; Huang, S.C. and Duh, P.D. (2002). Antioxidant activity of sesame coat. Food Chemistry, 78:347354.

Chu, W.L.; Yen-Wei, L.; Ammu, K.R. and Phaik-Eem, L. (2010). Protective effect of aqueous extract from Spirulina platensis against cell death induced by free radicals. MBC Complementary and Alternative medicine, 10:1-8. https://doi.org/10.1186/1472-6882-10-53

Dewick, P.M. (2001). Medicinal Natural Products. A Biosynthetic Approach, John Wiley \& Sons, UK., 520 p.

Dillard, C.J. and German, J.B. (2000). Phytochemicals: nutraceuticals and human health: A review. J. Sci. Food Agric., 80:1744-1756.

Duncan, D.B. (1955). Multiple range and multiple $\mathrm{F}$ test. Journal of Biometrics, 11:1-42.

Fakurazi, S.; Nanthini, U. and Hairuszah, I. (2012). Hepatoprotective and antioxidant action of Moringa oleifera Lam. against acetaminophen induced hepatotoxicity in rats. Int. J. Pharm., 4:270-275.

Falowo, A.B.; Muchenje, V.; Hugo, A., Aiyegoro O.A. and Fayemi, P.O. (2017). Antioxidant activities of Moringa oleifera L. and Bidens pilosa L. leaf extracts and their effects on oxidative stability of ground raw beef during refrigeration storage, CyTA-Journal of Food, 15(2):249-256.
Geleta, B.; Makonnen, E.; Debella, A. and Tadele, A. (2016). In vivo antihypertensive and antihyperlipidemic effects of the crude extracts and fractions of Moringa stenopetala (Baker f.) Cufod. leaves in rats. Front. Pharmacol., 7:1-10. https://doi.org/10.3389/fphar.2016.00097

Goupy, P.; Mireille, H.; Patrick, B. and Marie, J. (1999). Antioxidant composition and activity of barley (Hordeum vulgare) and malt extracts and of isolated phenolic compounds. Journal of the Science of Food and Agriculture, 79(12):1625-163.

Gülçin, İ; Şat, İ.G.; Beydemir, Ş. and Küfrevioğlu, Ö.İ. (2004). Evaluation of the in vitro antioxidant properties of extracts of broccoli (Brassica oleracea L.). Italian Journal of Food Sciences, 16:17-30.

Habtemariam, S. (2015). Investigation into the antioxidant and antidiabetic potential of Moringa stenopetala: identification of the active principles. Nat. Prod. Commun., 10(3):475-8.

Harborne, J.B. and Herbert, H. (1993). Phytochemical Dictionary, A Handbook of Bioactive Compounds from Plants. Taylor \& Francis Ltd., London, UK, 791 p.

Jonathan, S.G.; Olawuyi, O.J.; Aina, D.A.; Odeniyi, S.O.; Adediji, I.O. and Ikhedia, A. (2012). Comparative studies on antifungal, anti-oxidant and phytochemical potential of Momordica charantia and Moringa oleifera. New York Science Journal, 5(12):17-28.

Kähkönen, M.P.; Hopia, A.I.; Vuorela, H.J.; Rauha, J.P.; Pihlaja, K.; Kujala, T.S. and Heinonen, M. (1999). Antioxidant activity of plant extracts containing phenolic compounds. J. Agric. Food Chem., 47(10):3954-3962.

Leelavinothan, P.; Magdalena, K.; Agnieszka, K.; Anna, R. and Ryszard, A. (2007). Antioxidant activity of the crude extracts of drumstick tree (Moringa oleifera Lam.) and sweet broom weed 
(Scoparia dulcis L.) leaves. Pol. J. Food Nutr. Sci., 57:203-208.

Leone, A.; Spada, A.; Battezzati, A.; Schiraldi, A.; Aristil, J. and Bertoli, S. (2015). Cultivation, genetic, ethnopharmacology, phytochemistry and pharmacology of Moringa oleifera leaves: An overview. International Journal of Molecular Sciences, 16:12791-12835.

Mabberley, D.I. (1987). The Plant Book. Camb. Univ. Press, Cambridge, New York, USA, 720 p.

Maqsood, I.; Bushra, T.; Muzammil, H.N.; Wardha, M.; Zarafshan, B.; Ayesha, J. and Shahzadi, S. (2017). Pharmacokinetic study of atorvastatin after single dose administration among pakistani population. Pak. Armed Forces Med. J., 67(4):656-662.

Martin, M. and Guiochon, G. (2005). Effects of high pressure in liquid chromatography. Journal of Chromatography A. 1090:16-38.

Mbikay, M. (2012). Therapeutic potential of Moringa oleifera leaves in chronic hyperglycemia and dyslipidemia: A review. Front Pharmacol., 3:1-12. https://doi.org/10.3389/fphar.2012.00024

Mridha, M.A.U. (2015). Prospects of Moringa cultivation in Saudi Arabia. J. Appl. Environ. Biol. Sci., 5(3):39-46.

Nouman, W.; Farooq, A.; Tehseen, G.; Amaglo, N.; Eduardo, R. and Raúl, D.P. (2016). Profiling of polyphenolics, nutrients and antioxidant potential of germplasm's leaves from seven cultivars of Moringa oleifera Lam. Industrial Crops and Products, 83:166-176.

NRC (2006). Lost Crops of Africa, Vol. II, Vegetables Tables. The National Academies Press, Washington, DC., 378 p.

Ordoñez, A.A.L.; Gomez, J.G.; Vattuone, M.A. and Isla, M.I. (2006). Antioxidant activities of Sechiumedule (Jacq.) Swart extracts. Food Chem., 97:452-458.
Pirjo, M.; Astola, J. and Kumpulainen, J. (2000). Determination of flavonoids in plant material by HPLC with diode-array and electro-array detections. J. Agric. Food Chem., 48(12):5834-41.

Rajput, H.; Prasad, S.G.M.; Srivastav, P.; Singh, N.; Suraj, L. and Chandra, R. (2017). Chemical and phytochemical properties of fresh and dried Moringa oleifera (PKM-1) leaf powder. Chemical Science Review and Letters, 6(22):10041009.

Ramesh, K.S.; Iyyakkannu, S. and YoungSoo, K. (2016). Phytochemical of Moringa oleifera: a review of their nutritional, therapeutic and industrial significance. Biotech., 6:1-14. https://doi.org/10.1007/s13205-0160526-3

Re, R.; Pellegrini, N.; Proteggente, A.; Pannala, A.; Yang, M. and Rice-Evans, C. (1999). Antioxidant activity applying an improved ABTS radical cation decolorization assay. Free Radic. Biol. Med., 26(9-10):1231-7.

Rodríguez-Pérez, C.R.; Quirantes-Piné, A.; Fernández, G. and Segura-Carretero, A. (2015). Optimization of extraction method to obtain a phenolic compoundsrich extract from Moringa oleifera Lam leaves. Industrial Crops and Products, 66:246-254.

Shih, M.; Cheng-Ming, C.; Sue-Ming, K. and Min-Lang, T. (2011). Effect of different parts (leaf, stem and stalk) and seasons (summer and winter) on the chemical compositions and antioxidant activity of Moringa oleifera. Int. J. Mol. Sci., 12(9):6077-6088.

Singh, B.N.; Singh, B.R.; Singh, R.L.; Prakash, D.; Dhakarey, R.; Upadhyay, G. and Singh, H.B. (2009). Oxidative DNA damage protective activity, antioxidant and anti-quorum sensing potentials of Moringa oleifera. Food and Chemical Toxicology, 47(6):1109-1116. 
Snedecor, G.W. and Cochran, W.G. (1981). Statistical Methods 7. The Iowa state Univ., Press, Ames., Iowa, U.S.A.

Soares, J.R.; Dins, T.C.P.; Cunha, A.P. and Ameida, L.M. (1997). Antioxidant activity of some extracts of Thymus zygis. Free Radical Research, 26:469-478.

Solomon, H. and George, K. V. (2015). Extractability of rutin in herbal tea preparations of Moringa stenopetala leaves. Beverages, 1(3):169-182.

Statue-Gracia, M.T.; Heinonen, M. and Frankel, E.N. (1997). Antioxidant capacity of anthocyanin in LDL and lecithin liposome systems. Journal of Agricultural and Food Chemistry, 5:33623367.

Sulaiman, C.T.; Sadashiva, C.T.; Satheesh, G.; Goplakrishnan, V.K. and Indira, B. (2013). Chromatographic studies and in vitro screening for acetyl cholinesterase inhibition and antioxidant activity of three Acacia species from South India, Analytical Chemistry Letters, 3(2):111118.

Tekle, E.W.; Sahu, N.P. and Makesh, M. (2015). Antioxidative and antimicrobial activities of different solvent extracts of Moringa oleifera: an in vitro evaluation. International Journal of Scientific and Research Publications, 5(5):1-12.

Toma, A; Makonnen, E; Mekonnen, Y; Debella, A. and Addisakwattana, S.
(2014). Intestinal $\alpha$-glucosidase and some pancreatic enzymes inhibitory effect of hydroalcholic extract of Moringa stenopetala leaves. BMC Complementary and Alternative medicine, 14:1-5. https://doi.org/10.1186/1472-6882-14180.

Valdez-Solana, M.A.; Mejía-García, V.Y.; Téllez-Valencia, A.; García-Arenas, G.; Salas-Pacheco, J.; Alba-Romero, J.J. and Sierra-Campos, E. (2015). Nutritional content and elemental and phytochemical analyses of Moringa oleifera grown in Mexico. Journal of Chemistry, 9 p. https://doi.org/10.1155/2015/860381

Verma, A.R.; Vijaya,K. M.; Mathela, C.S. and Rao, C.V. (2009). In vitro and in vivo antioxidant properties of different fractions of Moringa oleifera leaves. Food and Chemical Toxicology, 47, (9): 21962201.

Vongsak, B.; Pongtip, S. and Wandee, G. (2013). Simultaneous HPLC quantitative analysis of active compounds in leaves of Moringa oleifera Lam. Journal of Chromatographic Science, 52(7):641645.

Wangcharoen, W. and Gomolmanee, S. (2011). Antioxidant capacity and total phenolics content of Moringa oleifera grown in Chiang Mai, Thailand. Thai Journal of Agricultural Science, 44(5):118-124.

$$
\begin{aligned}
& \text { تقدير مجموع المحتوي الفينولي والفلافونيدي والقوة المضادة للأكسدة و تعيينهم بإستخدام تقتية }
\end{aligned}
$$

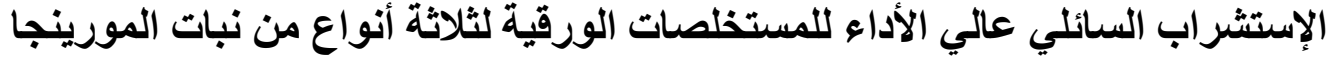

$$
\begin{aligned}
& \text { شمس رأفت أبو الفضل * ، علي عثمان ** ، أحمد منصور الزهيري *** ، عبير علي دهب* ، زكية أحمد أبو الخير **** }
\end{aligned}
$$

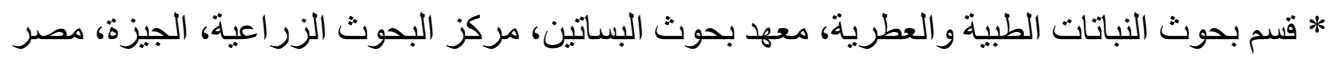

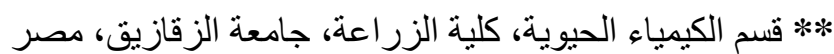

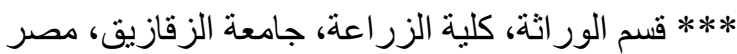

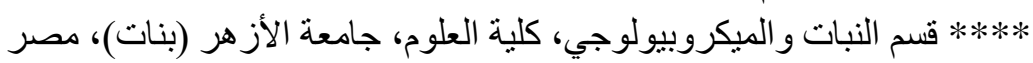

وفقا للار اسة الحالية فإنه نم إختبار ثلاثة أنواع من المورينجا ( مورينجا ستينوبيتالا، مورينجا بيريجرينا، مورينجا

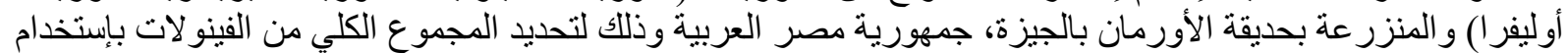

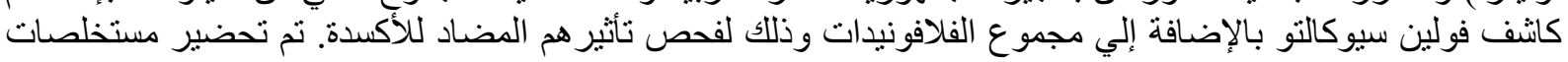




\section{Shams R. Abo El-Fadl et al.}

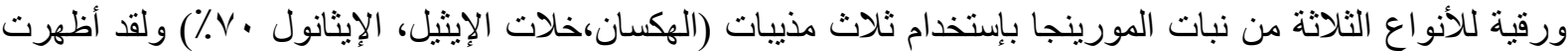

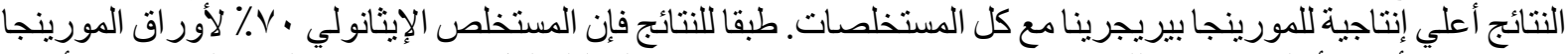

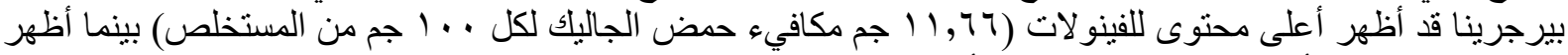

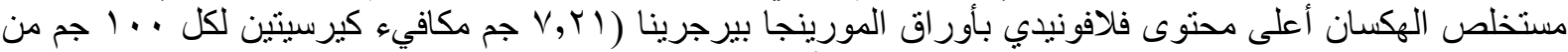

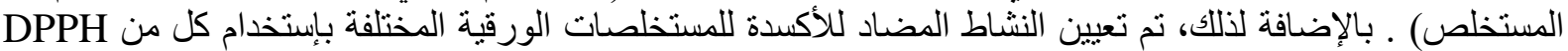

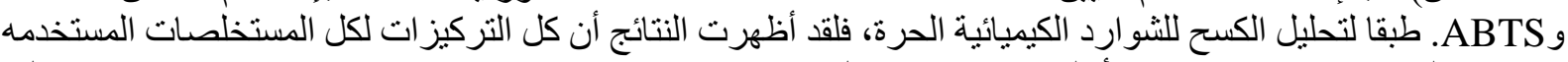

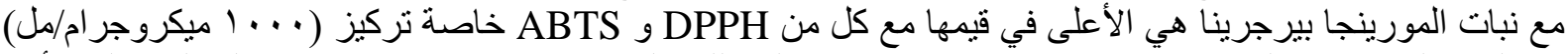

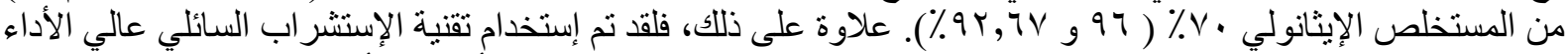

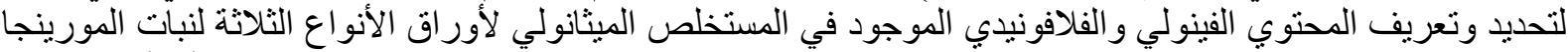

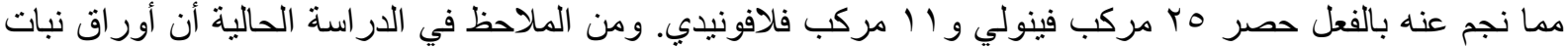

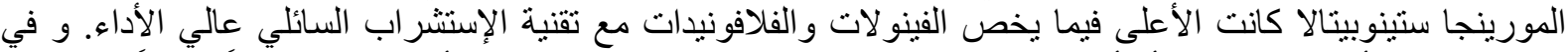

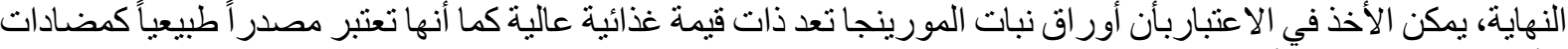

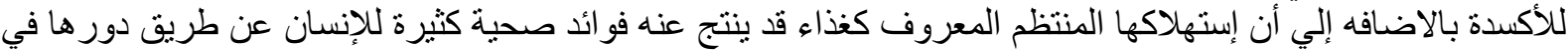
الحماية ضد الأكسدة. 